\title{
BEAM BOND TESTS OF GFRP AND STEEL REINFORCEMENT TO CONCRETE
}

\begin{abstract}
D. SZCZECH ${ }^{1}$, R. KOTYNIA ${ }^{2}$
The paper presents research program of bond between glass fiber reinforced polymer bars and concrete in reference to the steel bars. Bond between the reinforcement and concrete is a crucial parameter governing a behaviour of reinforced concrete members and transferring of the internal forces from concrete to the reinforcement. The use of FRP bars as an equivalent reinforcement to steel in concrete structures has increased in recent years. The FRP bars are very different from steel, mainly due to much lower elasticity modulus and their anisotropic structure. Good performance of FRP reinforced concrete requires sufficient interfacial bond between bars and concrete. However, there are no specific standards referring to the surface preparation of these bars, that leads to variable bond behaviour of the composite reinforcement to the concrete. The objective of the study was to investigate the influence of variable parameters on the bond behaviour to concrete. The experimental program consisted of eighteen beam bond specimens varying in: bar diameter $(12 \mathrm{~mm}, 16 \mathrm{~mm}, 18 \mathrm{~mm})$ and type of reinforcement (GFRP sand - coated and steel bars). Although the GFRP bars indicated good bond behaviour to concrete, the average bond strength was slightly lower than that of steel reinforcement of $16 \mathrm{~mm}$ and $18 \mathrm{~mm}$, while it was higher for the GFRP bars of $12 \mathrm{~mm}$ diameter.
\end{abstract}

Keywords: beam-bond test, failure, GFRP, steel, reinforcement, shear stress, slip

\section{INTRODUCTION}

Glass fiber reinforced polymer (GFRP) bars are the most common alternative to the steel reinforcement, while there are bars made of carbon and basalt fibers but not so popular as GFRP. The fundamental difference between GFRP reinforcement and steel is an anisotropic structure of the bars made of glass fibers and the much lower elasticity modulus comparing to steel. One of the most

\footnotetext{
${ }^{1}$ MSc., Eng., Lodz University of Technology, Faculty of Civil Engineering, Architecture and Environmental Engineering, al. Politechniki 6, 90-924 Łódź, Poland, e-mail: damian.szczech@p.lodz.pl

${ }^{2}$ Prof. PhD., Eng., Lodz University of Technology, Faculty of Civil Engineering, Architecture and Environmental Engineering, al. Politechniki 6,90-924 Łódź, Poland, e-mail: renata.kotynia@p.lodz.pl
} 
important parameter effecting behaviour of the concrete members reinforced with FRP reinforcement is bond of the bars to concrete highly dependent on the surface preparation. There are several reasons of using the non-metallic reinforcement: good non-magnetic properties, high strength, low weight in comparison to strength, good chemical and corrosion resistance.

Adequate interfacial bond between bars and concrete determines a good performance of the FRP reinforced concrete due to the transfer of tensile stress from the concrete matrix to the reinforcement. A bond behaviour between FRP bars and concrete is a complex mechanism, which requires consideration many factors. Bond-slip interaction between FRP bar and surrounding concrete is guaranteed by the stress propagation, which depends on a type of bars (its material and the surface preparation), bars geometry (shape and diameter), configuration of the reinforcement (concrete cover and the influence of the neighbouring bars), mechanical interaction, chemical adhesion, friction and the compressive strength of concrete. Furthermore, bond conditions depend on temperature, longterm loading or degradation of concrete.

The presented research concentrates on investigating bond behaviour of two types of bars (steel and GFRP) with three diameters $(12 \mathrm{~mm}, 16 \mathrm{~mm}$ and $18 \mathrm{~mm})$. The influence of the concrete cover, the bar diameter and the embedded length of the ribbed GFRP bars was investigated in the previous experimental tests conducted by the authors [7]. The review of the existing research on the FRP-toconcrete bond behaviour demonstrated that unlike conventional steel bars, the FRP reinforcement did not meet the unified standards for the surface preparation. The following variable types of surface preparation are commonly used: sand covering (with different size of grain), ribbing with fiber braid (with variable types of ribs and their shape, rib spacing, surface of the rib in relation to the bar surface), spirally wound ribs on the bar surface (parallel ribs winding), cross, spiral pitch, ribs performed by cutting grooves in the surface of the bar and the combination of different braids with sand powders [2].

A lot of research of the bond behaviour of FRP reinforcement to concrete based on: direct pull-out test, splice test and ring pull-out test $[1,4,6,8]$. Direct and ring pull-out tests do not correspond to the real bond conditions in reinforced concrete members. The best known and most commonly used methods of bond testing recommended (for steel bars) by the RILEM Institute [11] include the pullout and the beam-bond tests. The only beam-bond test and splice test can reflect the actual bond behaviour of the reinforcement to concrete in RC members subjected to flexure. Not much research has been done on the beam bond-tests with FRP reinforcement $[5,9,13]$. The procedure of the beambond tests employed in the presented study is based on the PN-EN 10080 standard [10]. 
The presented research of the bond behaviour of GFRP bars to concrete based on a wide state of the art of the existing experimental FRP to concrete bond tests. Generally, the GFRP bars exhibited a good bond behaviour in all of the investigated research. The ultimate bond strength of the FRP bars to concrete was close to approx. $85 \%$ of the ultimate bond strength of the steel reinforcement [12]. Nevertheless, the GFRP bars reached lower bond stress than the CFRP bars [12]. The influence of the surface preparation of FRP bars on the bond conditions is frequently more substantial than that of other parameters (concrete strength or modulus of elasticity of FRP bars). What is more, FRP reinforcement indicates lower bond strength to concrete than steel bars of the same diameter [13]. It is mostly because of the ribs, which in most GFRP bars are superficially sheared off from the bar core.

The majority of beam-bond tests confirmed that the loss of bond was the main mode of failure for the bond length lower than $20 \varnothing$ (where, $\varnothing$ is the bar diameter) [5,9]. For higher bond lengths, rupture of the bars was the most often observed.

The research [5] indicated that the increase in the slip of the loaded end $\left(s_{l p}\right)$ and the bond length $\left(L_{b}\right)$ was more pronounced in the ribbed bars than in the sand coated bars. Another tests[13] confirmed that the ribbed bars displayed the higher bond stiffness and bond shear stress $(\tau)$ than the sand-coated bars. Generally, an increase in the FRP bar's diameter resulted in a decrease in the shear bond stress and in a reduction in the final slip of the rod, similarly to the steel bars $[5,12,13]$. This tendency was more distinct in the case of the higher compressive concrete strength [2]. Mazaheripour indicated in the tests [5] an increase in the bond stress with an increase in the concrete cover, especially for bars of larger diameter.

Regardless of a number of bond tests conducted on the FRP bars, this is still an up-to-date issue, which requires a fundamental analysis of the failure mechanisms dependent on the surface preparation of the FRP reinforcement.

\section{EXPERIMENTAL PROGRAM}

\subsection{TEST SPECIMENS}

The aim of the tests was to determine the bond behaviour of GFRP bars to concrete on the beam-bond setup. The specimens composed of two prismatic blocks were connected by one GFRP or steel bar (of $12 \mathrm{~mm}, 16 \mathrm{~mm}$ or $18 \mathrm{~mm}$ diameter) as the flexural reinforcement at the bottom part, and a steel hinge at the top zone (Fig. 1). A test program contained eighteen rectangular concrete beams with a 
cross section of $100 \times 200 \mathrm{~mm}$ and the total length of $820 \mathrm{~mm}$. In the central front part of each nontested block, the bar was unbonded on the length of $50 \mathrm{~mm}$ to avoid premature fracture of concrete in the central loaded edge zone. The embedment length in the non-tested block was unchanged in all specimens equal of $335 \mathrm{~mm}$. In the opposite tested block, the bar was unbonded on the length of 150 $\mathrm{mm}$ and the embedment length was $5 \varnothing$ (changing according to the bar's diameter $\varnothing$ ) the rest of the free end of the bars was unbonded (Fig. 1). The specimen details are presented in Table 1 .

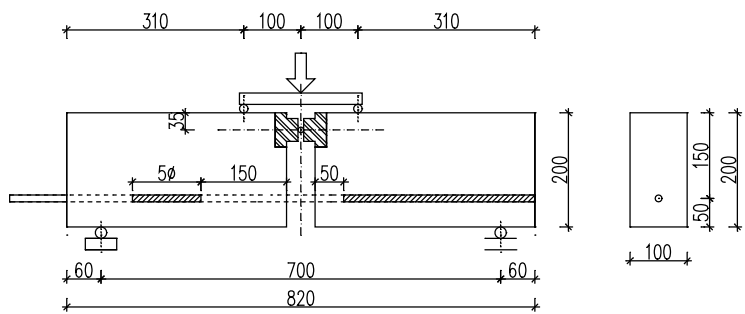

Fig. 1. Beams geometry

The steel stirrups, diameter of $8 \mathrm{~mm}$, spacing $70 \mathrm{~mm}$ were used to avoid shear failure. The top and the bottom reinforcement was made with two steel bars of $10 \mathrm{~mm}$ diameter. In the mid height of the beam there were two additional steel bars with a diameter of $10 \mathrm{~mm}$ (Fig. 2). The distance of the centre of the analysed GFRP/steel bars from the bottom edge of the beam was established as constant and equal of $50 \mathrm{~mm}$.

The beam's nomenclature consists of: type of the bar (GS - glass sand-coated surface /S - steel bars); bars diameter; bond length ( 5 times diameter) and the beam's number from three beams with the same configuration.

Table 1. Specimen details

\begin{tabular}{|c|c|c|c|}
\hline Element & Rebar surface treatment & $\begin{array}{l}\text { Nominal } \\
\text { diameter }\end{array}$ & Bond length \\
\hline GS-12-5.1 & \multirow{9}{*}{ glass sand-coated surface } & & \multirow{16}{*}{$5 \varnothing$} \\
\hline GS-12-5.2 & & $12 \mathrm{~mm}$ & \\
\hline GS-12-5.3 & & & \\
\hline GS-16-5.1 & & & \\
\hline GS-16-5.2 & & $16 \mathrm{~mm}$ & \\
\hline GS-16-5.3 & & & \\
\hline GS-18-5.1 & & & \\
\hline GS-18-5.2 & & $18 \mathrm{~mm}$ & \\
\hline GS-18-5.3 & & & \\
\hline S-12-5.1 & \multirow{7}{*}{ steel bars } & & \\
\hline S-12-5.2 & & $12 \mathrm{~mm}$ & \\
\hline S-12-5.3 & & & \\
\hline S-16-5.1 & & & \\
\hline S-16-5.2 & & $16 \mathrm{~mm}$ & \\
\hline S-16-5.3 & & & \\
\hline S-18-5.1 & & $18 \mathrm{~mm}$ & \\
\hline
\end{tabular}



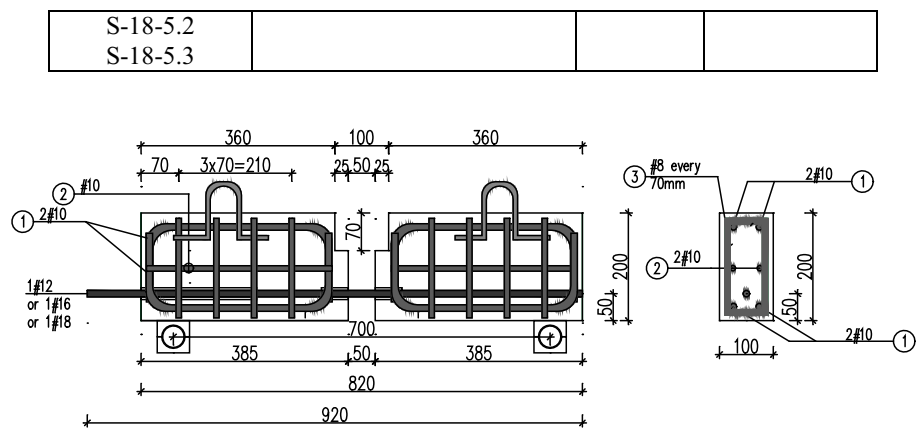

Fig. 2. Reinforcement of beams

\subsection{MATERIAL CHARACTERISTICS}

Two kinds of bars were used in the bond tests: GFRP bars sand - coated with ribs and steel bars of B500A class. The strength parameters of the bars were determined in the tensile test on three samples taken from each batch. Strength characteristics of the used reinforcement is shown in Table 2 (the average values of: yield strength $f_{\text {sym }}$, ultimate strength $f_{\text {sum }}$ and secant modulus of elasticity $E_{s}$ ).

Table 2. Properties of GFRP and steel bars

\begin{tabular}{|c|c|c|c|c|}
\hline \multirow{2}{*}{$\begin{array}{c}\text { Type of the bar } \\
\text { surface }\end{array}$} & \multirow{2}{*}{ Bar diameter $\varnothing$} & \multicolumn{3}{|c|}{ Mechanical properties } \\
\cline { 2 - 5 } & & $f_{\text {sym }}(\sigma)$ & $f_{\text {sum }}(\sigma)$ & $E_{s}(\sigma)$ \\
\hline- & {$[\mathrm{mm}]$} & {$[\mathrm{MPa}]$} & {$[\mathrm{MPa}]$} & {$[\mathrm{GPa}]$} \\
\hline \multirow{3}{*}{ Steel bars } & $\# 12$ & $522.4(5.4)$ & $650.3(5.8)$ & $198.3(3.0)$ \\
\cline { 2 - 5 } & $\# 16$ & $567.9(2.1)$ & $675.8(0.4)$ & $201.3(0.9)$ \\
\cline { 2 - 5 } & $\# 18$ & $557.0(1.5)$ & $641.1(1.0)$ & $204.6(5.7)$ \\
\hline \multirow{2}{*}{$\begin{array}{c}\text { GFRP bars } \\
\text { sand - coated }\end{array}$} & $\# 12$ & --- & $1164(30)$ & $56.4(5.1)$ \\
\cline { 2 - 5 } & $\# 16$ & --- & $913.3(25)$ & $43.4(1.0)$ \\
\cline { 2 - 5 } & $\# 18$ & --- & $1085.0(42)$ & $53.9(2.5)$ \\
\hline
\end{tabular}

The concrete mix was composed of: sand $0 / 2-830 \mathrm{~kg} / \mathrm{m}^{3}$, crushed stone $2 / 8-1040 \mathrm{~kg} / \mathrm{m}^{3}$, water $180 \mathrm{~kg} / \mathrm{m}^{3}$, cement CEM I 52.5 Rudniki CEMEX - $270 \mathrm{~kg} / \mathrm{m}^{3}$, plasticizer BV- Cemex Admixtures $1,9 \mathrm{~kg} / \mathrm{m}^{3}$. Concrete consistency was $\mathrm{S} 3$ and water to cement ratio $\mathrm{w} / \mathrm{c}=0.67$.

Concrete cylinders of $150 \mathrm{~mm}$ diameter and $300 \mathrm{~mm}$ height and cubic samples of $150 \mathrm{~mm}$ side casted together with the beams were used to determine the concrete strength the same day as the beams were tested. The compressive strength $\left(f_{c, c u b e}\right)$ and tensile by splitting $\left(f_{c t}\right)$ concrete strength were determined on the cubic concrete samples, while the column strength $\left(f_{c}\right)$ and modulus of elasticity $\left(E_{c}\right)$ were determined on the cylindrical samples. The average values of concrete strength properties are presented in Table 3 with standard deviation given in brackets. 
Table 3. Strength characteristics of concrete

\begin{tabular}{|c|c|c|c|c|c|}
\hline Element & $\begin{array}{c}\text { Age } \\
{[\text { days }]}\end{array}$ & $\begin{array}{c}f_{c, \text { cube }}(\sigma) \\
{[\mathrm{MPa}]}\end{array}$ & $\begin{array}{c}f_{c t}(\sigma) \\
{[\mathrm{MPa}]}\end{array}$ & $\begin{array}{c}f_{c}(\sigma) \\
{[\mathrm{MPa}]}\end{array}$ & $\begin{array}{c}E_{c}(\sigma) \\
{[\mathrm{GPa}]}\end{array}$ \\
\hline GS-12-5 & 65 & $36.2(1.2)$ & $3.2(0.2)$ & $32.2(1.1)$ & $28.5(0.3)$ \\
\hline GS-16-5 & 40 & $34.0(1.6)$ & $3.0(0.4)$ & $31.9(2.0)$ & $29.1(0.8)$ \\
\hline GS-18-5 & 67 & $36.1(2.1)$ & $3.2(0.1)$ & $32.2(1.3)$ & $27.8(0.9)$ \\
\hline S-12-5 & 83 & $36.9(1.8)$ & $3.2(0.3)$ & $32.7(0.7)$ & $28.4(0.7)$ \\
\hline S-16-5 & 84 & $37.3(2.8)$ & $3.2(0.2)$ & $32.5(1.2)$ & $27.9(0.5)$ \\
\hline S-18-5 & 92 & $38.0(2.2)$ & $3.6(0.4)$ & $33.4(0.7)$ & $29.3(0.4)$ \\
\hline
\end{tabular}

\subsection{TEST SETUP AND TEST MEASUREMENTS}

The test stand was composed of the steel frame girders, hydraulic jack attached to the upper frame and the servo-motor device for a displacement control loading, steel hinged supports (with a movable one in the tested concrete block) and the computer measurements statement (Fig. 3). Two point loading scheme was performed by the steel cross-beam. The load was applied monotonically, by the displacement control hydraulic jack of $200 \mathrm{kN}$ capacity, with velocity of $10 \mu \mathrm{m} / \mathrm{s}$.

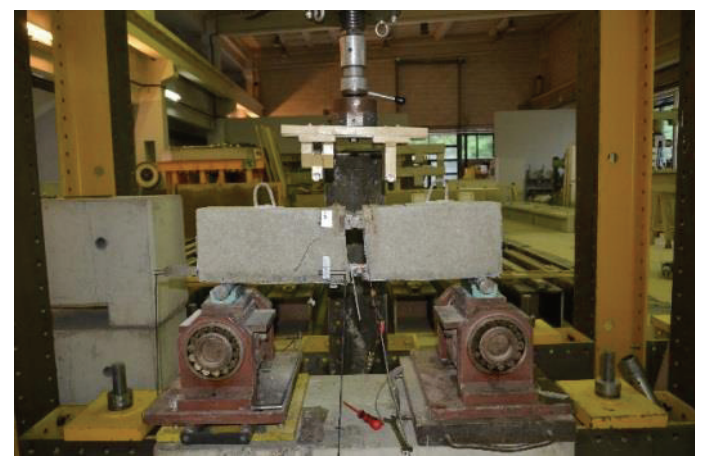

Fig. 3. Test setup

The measuring device consisted of two linear variable differential transducers (LVDT) and the strain gauge. To measure a slip at the loaded $\left(s_{l p}\right)$ and free $\left(s_{f p}\right)$ ends of GFRP and steel bars, LVDT no 1 and LVDT no 4 were used, respectively. The LVDT no 1 was fixed to the free end bar to measure the relative displacement between the bar and the front surface of the tested concrete block, while LVDT no 4 was fixed to the free extremity of the bar and measured the relative displacement between the free end bar and the external surface of the tested concrete block. The strain gauge was installed in the mid- 
span cross-section of the bar to record the strains in the bar. A scheme of measurements is shown in Fig. 4. The all measurements reading were recorded continuously and automatically every one second.

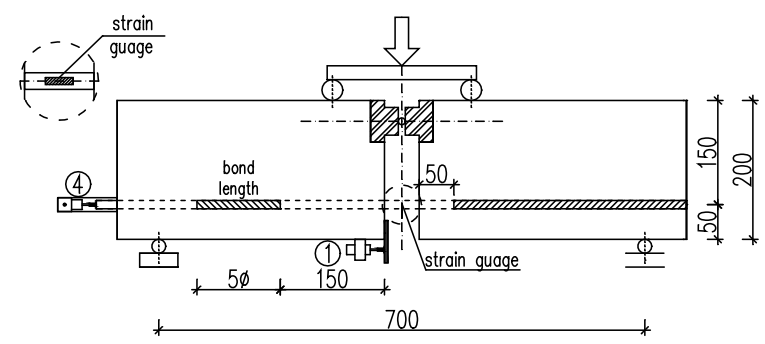

Fig. 4. Scheme of measurements

\section{THE ANALYSIS OF THE TEST RESULTS}

\subsection{FAILURE MODES}

The pull-out failure mode was observed in the all specimens irrespectively of the variable parameters: bar diameter and type of bars (GFRP or steel). A concrete cover of each test block was cut after the test and the concrete cover was removed in order to make a clear verification of the failure mode along the bond length. From the visual inspection of the interface between the bar and concrete, it could be seen that the sand coat had been completely sheared off of the GFRP bars along the entire embedment length. Bond failure of the GFRP bars developed partially along the surface of the bars and partially in the surrounding concrete by locally sheared off the external sand coated surface of the bar (Fig. 5), while the steel bars were undamaged.
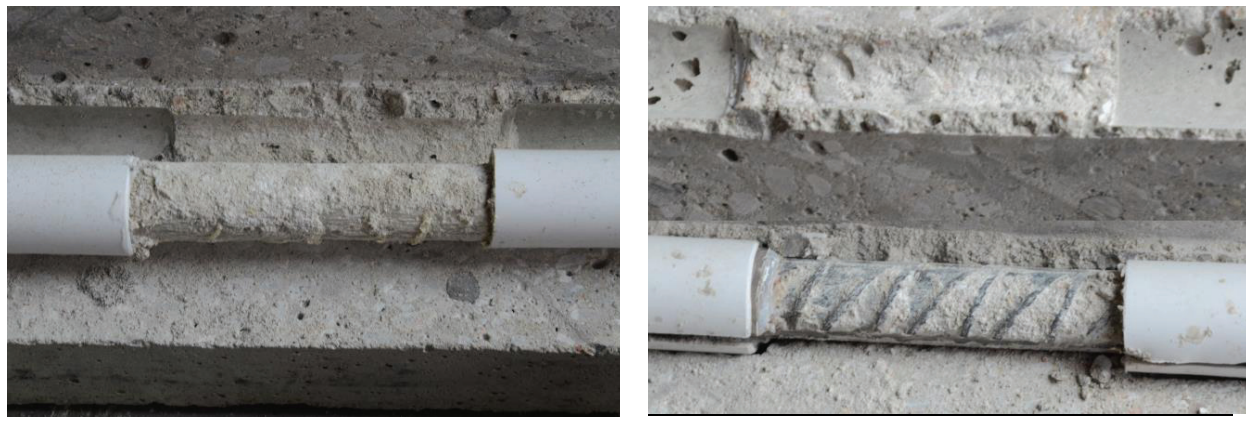

Fig. 5. Failure of the GFRP bar (GS-18-5.3) and steel bar (S-16-5.3) along the embedded length 


\subsection{EXPERIMENTAL RESULTS AND ULTIMATE BOND STRESSES}

The maximum pull-out force in the bar $\left(F_{u}\right)$ was calculated based on the ultimate load $\left(F_{\max }\right)$. The ultimate bond stress of the bar $\left(\tau_{u}\right)$, defined as an average bond shear stress over the embedded length was calculated according to the equation (1):

$$
\tau_{u}=\frac{F_{u}}{\pi \cdot \phi \cdot L_{b}}
$$

where: $\mathrm{F}_{\mathrm{u}}$ is the maximum pull-out force, $\varnothing$ is the nominal bar diameter and $\mathrm{L}_{\mathrm{b}}$ is the embedded bond length.

All test results containing the average bond stress $(\tau)$ and bar's slip of the loaded and free end $\left(s_{l p}, s_{f p}\right)$ are shown in Table 5. To ensure the sufficient bond strength of bars to concrete, the bond stresses obtained in the test should meet the standard stress values defined acc. to Appendix C (Eurocode 2) as the mean value of bond stress at failure by slipping $\left(\tau_{\max }\right)$ and the average values of bond stresses at slip equal of $0.01 \mathrm{~mm}\left(\tau_{0.01}\right), 0.1 \mathrm{~mm}\left(\tau_{0.1}\right)$ and $1 \mathrm{~mm}\left(\tau_{l}\right)$. The all test results and required values are summarized in Table 4 . The average values from the trials have been bolded.

Table 4. Test results

\begin{tabular}{|c|c|c|c|c|c|c|c|c|c|c|}
\hline Element & \multirow{2}{*}{$\begin{array}{c}\varnothing \\
\text { mean val. })\end{array}$} & $\begin{array}{c}F_{\max } \\
{[\mathrm{mm}]}\end{array}$ & $\begin{array}{c}s_{l p} \\
{[\mathrm{kN}]}\end{array}$ & $\begin{array}{c}S_{f p} \\
{[\mathrm{~mm}]}\end{array}$ & $\begin{array}{c}\tau_{0.01} \\
{[\mathrm{~mm}]}\end{array}$ & $\begin{array}{c}\tau_{0.1} \\
{[\mathrm{MPa}]}\end{array}$ & $\begin{array}{c}\tau_{l} \\
{[\mathrm{MPa}]}\end{array}$ & $\begin{array}{c}\tau_{u} \\
{[\mathrm{MPa}]}\end{array}$ & \multicolumn{2}{|c|}{ Eurocode 2} \\
\hline GS-12-5.1 & 12 & 30.83 & 1.12 & 0.23 & 7.8 & 14.6 & 14.0 & 14.8 & $\begin{array}{c}\tau_{\max } \\
{[\mathrm{MPa}]}\end{array}$ & $\begin{array}{c}\tau_{\text {mean }} \\
{[\mathrm{MPa}]}\end{array}$ \\
\hline GS-12-5.2 & 12 & 30.21 & 1.40 & 0.28 & 9.1 & 12.8 & 11.7 & 14.5 & 10.5 & 6.4 \\
\hline GS-12-5.3 & 12 & 26.35 & 1.00 & 0.13 & 7.7 & 12.5 & 9.2 & 12.7 & 10.5 & 6.4 \\
\hline (GS-12-5) & $\mathbf{1 2}$ & $\mathbf{2 9 . 1 3}$ & $\mathbf{1 . 1 7}$ & $\mathbf{0 . 2 1}$ & $\mathbf{8 . 2}$ & $\mathbf{1 3 . 3}$ & $\mathbf{1 1 . 6}$ & $\mathbf{1 4 . 0}$ & $\mathbf{1 0 . 5}$ & $\mathbf{6 . 4}$ \\
\hline GS-16-5.1 & 16 & 43.30 & 1.06 & 0.14 & 6.5 & 11.5 & 9.8 & 11.7 & 9.8 & 6.0 \\
\hline GS-16-5.2 & 16 & 38.27 & 1.33 & 0.15 & 8.0 & 9.9 & 9.5 & 10.3 & 9.8 & 6.0 \\
\hline GS-16-5.3 & 16 & 44.60 & 1.01 & 0.05 & 6.4 & 11.5 & 11.0 & 12.1 & 9.8 & 6.0 \\
\hline (GS-16-5) & $\mathbf{1 6}$ & $\mathbf{4 2 . 0 6}$ & $\mathbf{1 . 1 3}$ & $\mathbf{0 . 1 1}$ & $\mathbf{7 . 0}$ & $\mathbf{1 1 . 0}$ & $\mathbf{1 0 . 0}$ & $\mathbf{1 1 . 4}$ & $\mathbf{9 . 8}$ & $\mathbf{6 . 0}$ \\
\hline GS-18-5.1 & 18 & 46.74 & 1.09 & 0.13 & 4.7 & 9.5 & 7.8 & 10.0 & 9.4 & 5.7 \\
\hline GS-18-5.2 & 18 & 53.72 & 1.06 & 0.21 & 6.3 & 10.3 & 11.1 & 11.6 & 9.4 & 5.7 \\
\hline GS-18-5.3 & 18 & 55.47 & 1.28 & 0.23 & 6.0 & 10.3 & 10.8 & 11.8 & 9.4 & 5.7 \\
\hline (GS-18-5) & $\mathbf{1 8}$ & $\mathbf{5 1 . 9 8}$ & $\mathbf{1 . 1 4}$ & $\mathbf{0 . 1 9}$ & $\mathbf{5 . 7}$ & $\mathbf{1 0 . 0}$ & $\mathbf{9 . 9}$ & $\mathbf{1 1 . 1}$ & $\mathbf{9 . 4}$ & $\mathbf{5 . 7}$ \\
\hline S-12-5.2 & 12 & 23.03 & 0.87 & 0.77 & 3.5 & 7.0 & 10.9 & 11.1 & 10.5 & 6.4 \\
\hline S-12-5.3 & 12 & 21.40 & 0.98 & 0.71 & 1.6 & 2.8 & 10.3 & 10.3 & 10.5 & 6.4 \\
\hline (S-12-5) & $\mathbf{1 2}$ & $\mathbf{4 4 . 4 3}$ & $\mathbf{0 . 9 3}$ & $\mathbf{0 . 7 4}$ & $\mathbf{2 . 6}$ & $\mathbf{4 . 9}$ & $\mathbf{1 0 . 6}$ & $\mathbf{1 0 . 7}$ & $\mathbf{1 0 . 5}$ & $\mathbf{6 . 4}$ \\
\hline S-16-5.1 & 16 & 45.53 & 0.63 & 0.41 & 6.0 & 9.5 & 11.6 & 12.3 & 9.8 & 6.0 \\
\hline S-16-5.2 & 16 & 54.93 & 0.85 & 0.36 & 6.5 & 12.1 & 13.7 & 14.8 & 9.8 & 6.0 \\
\hline S-16-5.3 & 16 & 44.25 & 0.64 & 0.42 & 3.2 & 9.0 & 11.4 & 12.0 & 9.8 & 6.0 \\
\hline (S-16-5) & $\mathbf{1 6}$ & $\mathbf{4 8 . 2 4}$ & $\mathbf{0 . 7 1}$ & $\mathbf{0 . 4 0}$ & $\mathbf{5 . 2}$ & $\mathbf{1 0 . 2}$ & $\mathbf{1 2 . 2}$ & $\mathbf{1 3 . 0}$ & $\mathbf{9 . 8}$ & $\mathbf{6 . 0}$ \\
\hline S-18-5.1 & 18 & 64.39 & 0.57 & 0.42 & 6.2 & 11.3 & 12.8 & 13.8 & 9.4 & 5.7 \\
\hline
\end{tabular}




\begin{tabular}{|l|l|l|l|l|l|l|l|l|l|l|}
\hline S-18-5.2 & 18 & 54.60 & 0.64 & 0.39 & 4.0 & 9.7 & 11.2 & 11.7 & 9.4 & 5.7 \\
\hline S-18-5.3 & 18 & 54.08 & 0.74 & 0.45 & 2.7 & 8.9 & 10.9 & 11.6 & 9.4 & 5.7 \\
\hline (S-18-5) & $\mathbf{1 8}$ & $\mathbf{5 7 . 6 9}$ & $\mathbf{0 . 6 5}$ & $\mathbf{0 . 4 2}$ & $\mathbf{4 . 3}$ & $\mathbf{1 0 . 0}$ & $\mathbf{1 1 . 6}$ & $\mathbf{1 2 . 4}$ & $\mathbf{9 . 4}$ & $\mathbf{5 . 7}$ \\
\hline
\end{tabular}

Test results indicated that the increase in the bar diameter caused the decrease in the free bar end slip corresponding to the ultimate shear bond stress $\left(\tau_{u}\right)$. GFRP bars with sand coated surface of $12 \mathrm{~mm}$ diameter indicated the higher bond strength than the same bars of $16 \mathrm{~mm}$ diameter, similar to GFRP bars of $16 \mathrm{~mm}$ diameter, which indicated the higher bond strength than the same bars of $18 \mathrm{~mm}$ diameter. The increase in the GFRP bar diameter from $12 \mathrm{~mm}$ to $16 \mathrm{~mm}$ indicated the decrease in the ultimate shear bond stress $\left(\tau_{u}\right)$ by $18.6 \%$. For the same type of bars, the increase in the bar diameter from $16 \mathrm{~mm}$ to $18 \mathrm{~mm}$ confirmed the decrease in the ultimate shear bond stress $\left(\tau_{u}\right)$ by $3 \%$. Previous beam-bond tests carried out by the authors on different GFRP ribbed bars (without sand on the surface) indicated a decrease in the bond strength with the increase in the bar diameter [7].

The steel bars indicated different bond behaviour comparing to the GFRP bars. The steel bars with embedded length $5 \varnothing$ showed the increase in the ultimate shear bond stress $\left(\tau_{u}\right)$ by $21.5 \%$ with the increase in the bar diameter from $12 \mathrm{~mm}$ to $16 \mathrm{~mm}$. With increase in a diameter from $16 \mathrm{~mm}$ to $18 \mathrm{~mm}$ showed the decrease in the bond strength by $4.6 \%$.

The mean values of ultimate shear bond stresses $\left(\tau_{u}\right)$ for all bars was higher than the required calculated mean value of the bond stress at failure by slipping $\left(\tau_{\max }\right)$. The required calculated average values $\left(\tau_{\text {mean }}\right)$ of bond stresses at slip equal of $0.01 \mathrm{~mm}\left(\tau_{0.01}\right), 0.1 \mathrm{~mm}\left(\tau_{0.1}\right)$ and $1 \mathrm{~mm}\left(\tau_{1}\right)$ were satisfied for all specimens, that confirmed that both GFRP bars with sand-coated surface and steel bars indicated good bond behaviour to concrete.

\subsection{BOND - SLIP RELATIONSHIP}

Comparison of bond behaviour for the tested bars (three specimens for one member) are shown in Figures 6 - 9. The curves show the bond stress-slip curves for exhibited different bond behaviour for GFRP bars and steel bars for loaded (Fig. 6 and Fig. 8) and free bar's end (Fig. 7 and Fig. 9). In the case of GFRP bars, following the peak load the pull-out force quickly dropped with the slip increase leading abrupt bond losing between GFRP bars and concrete. In the case of bars $16 \mathrm{~mm}$ and $18 \mathrm{~mm}$ diameter the bond stress for the steel bars was higher than that for GFRP bars and contrary to the diameter of $12 \mathrm{~mm}$, the bond stress in the steel bars was lower than that for GFRP bars. 
Figures 10 - 12 show the influence of bar diameter for both types of bars. Results of steel bars show the increase in the ultimate bond stress with the increase in the bar diameter. In case of GFRP bars the increase in the bar diameter caused the decrease in the shear bond stress.

Test results of GFRP bars show an abrupt decrease in the shear stress after reaching the peak bond stress comparing to the slower decrease in relation to the steel bars.

Figures 10 - 12 present a comparison of the sand - coated GFRP bars and steel bars for the same bar diameter $(12 \mathrm{~mm}, 16 \mathrm{~mm}, 18 \mathrm{~mm}$, respectively). The bond losing of steel bars is milder than that of GFRP bars.
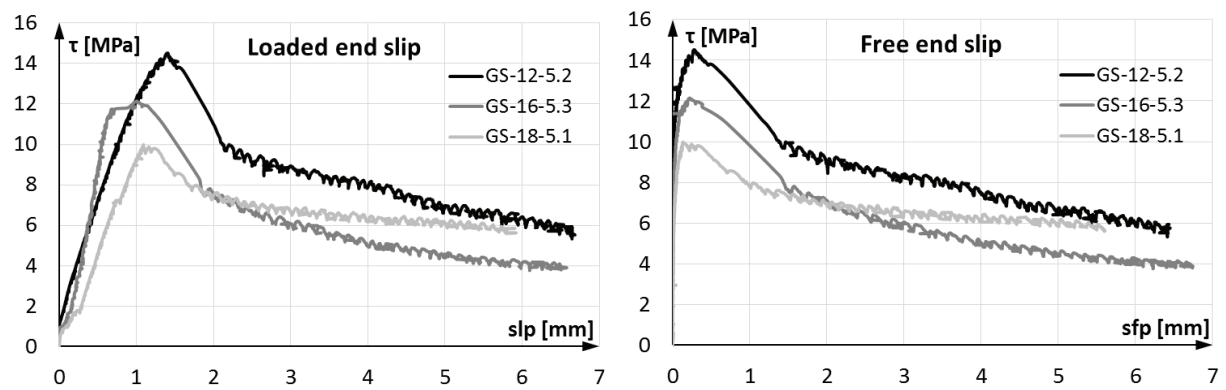

Fig. 6. Loaded end slip-bond stress plot for GFRP bars Fig. 7. Free end slip-bond stress plot for GFRP bars
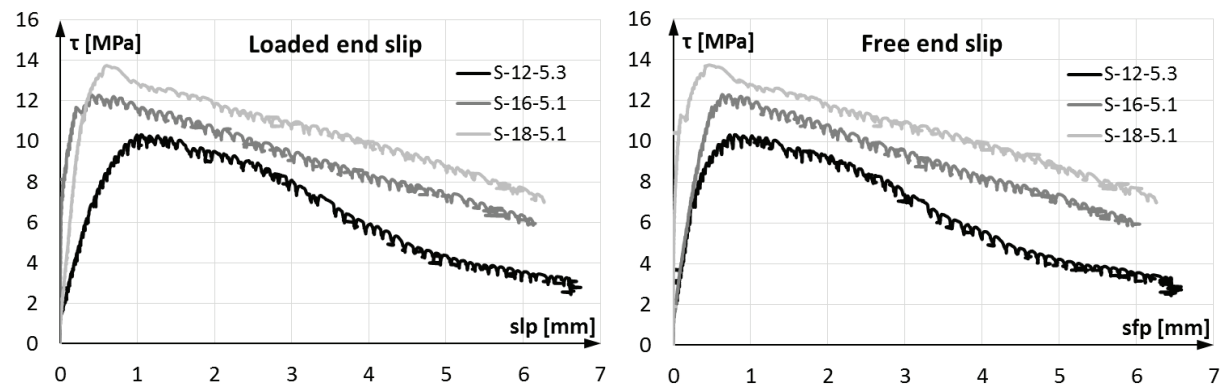

Fig. 8. Loaded end slip-bond stress plot for steel bars

Fig. 9. Free end slip-bond stress plot for steel bars
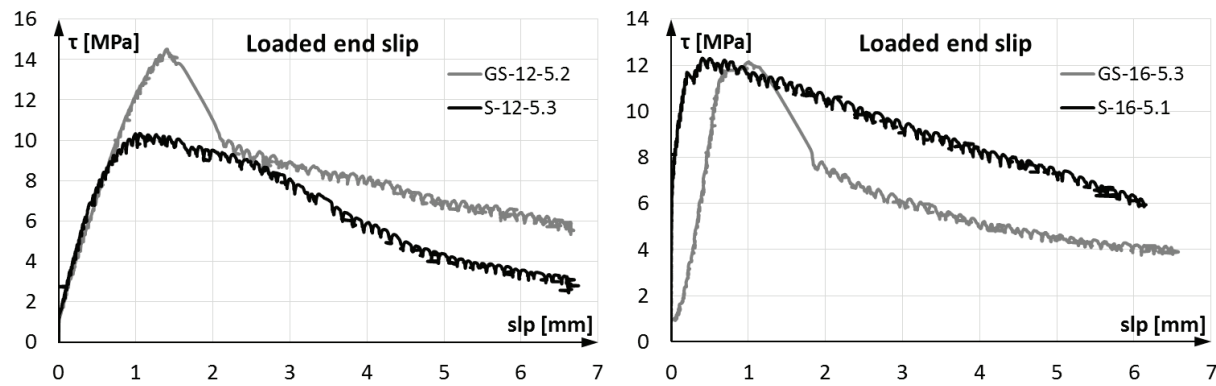
Fig. 10. Loaded end slip-bond stress plot for GFRP Fig. 11. Loaded end slip-bond stress plot for GFRP and steel bars of $12 \mathrm{~mm}$ diameter and steel bars of $16 \mathrm{~mm}$ diameter

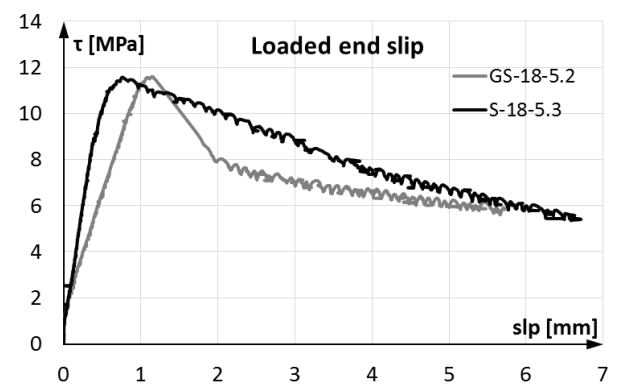

Fig. 12. Loaded end slip-bond stress plot for GFRP and steel bars of $18 \mathrm{~mm}$ diameter

\section{CONCLUSiOnS}

The paper present a part of extensive research program of the bond behaviour of the sand-coated GFRP and steel bars to the concrete. Eighteen beams were investigated to determine an influence of the bar diameter and a type of the bars on the bond strength and failure modes. The GFRP bars with sand - coated surface indicated a good bond behaviour with respect to the steel bars. All specimens were characterized by pullout mode of bond failure irrespectively to the bar's diameter. The sand-coated surface in the GFRP bars was sheared off. The increase in the bar diameter caused the decrease in the ultimate shear bond stress $\left(\tau_{u}\right)$. The required mean values of the bond stress at failure by slipping $\left(\tau_{\max }\right)$ and average values of bond stresses $\left(\tau_{\text {mean }}\right)$ at slip equal of $0.01 \mathrm{~mm}, 0.1 \mathrm{~mm}$ and $1 \mathrm{~mm}$ were satisfied for all kind of bars, which confirmed that the GFRP with sand-coated surface and steel bars confirmed good bond behaviour to the concrete.

\section{ACKNOWLEDGEMENTS}

The authors gratefully acknowledge the PREFA KOMPOSITY A.S., who supplied the GFRP reinforcement for the experimental tests.

\section{REFERENCES}

1. AL-Mahmoud F, Castel A, Francois R, Tourneur C. "Effect of surface preconditioning on bond of carbon fibre reinforced polymer rods to concrete". Cement \& Concrete Composites 2007;29(9):677-89.

2. Baena M, Torres L, Turon A, Barris C. "Experimental study of bond behaviour between concrete and FRP bars using a pull-out test”. Composites: Part B 2009;40(8):784-97. 
3. Fei Yan, Zhibin Lin, Mijia Yang. "Bond mechanism and bond strength of GFRP bars to concrete: A review". Composites Part B 98 (2016) 56-69.

4. Hao Q, Wang Y, He Z, Ou J. "Bond strength of glass fibre reinforced polymer ribbed rebars in normal strength concrete". Construction Build Mater 2009;23(2):865-71.

5. H. Mazaheripour, J.A.O. Barros, J.M. Sena-Cruz, M. Pepe, E. Martinelli. "Experimental study on bond performance of GFRP bars in self-compacting steel fibre reinforced concrete". Composite Structure, 95 (2013), 202-212.

6. Won Jong-Pil, Chan-Gi Park, Hwang-Hee Kim, Sang-Woo Lee, Chang-Il Jang. "Effect of fibres on the bonds between FRP reinforcing bars and high-strength concrete". Composites Part B: Engineering, Volume 39, Issue 5, July 2008, Pages 747-755.

7. Kotynia, R., Szczech, D., Kaszubska, M. "Bond behaviour of GRFP bars to concrete in beam test". Procedia Engineering 2017, (193), 401-408.

8. Lee JY, Kim TY, Kim TJ, Yi CK, Park JS, et al. „Interfacial bond strength of glass fibre reinforced polymer bars in high-strength concrete". Composites: Part B 2008;39(2):258-70.

9. Pecce M, Manfredi G, Realfonzo R, Cosenza E. "Experimental and analytical evaluation of bond properties of GFRP bars". Journal of Materials in Civil Engineering 2001;13(4):282-90.

10. PN-EN 10080:2007. Steel for the reinforcement of concrete. Wieldable reinforcing steel. General

11. RILEM. "Bond test for reinforcement steel 2. Pullout test". Recommendation RC6, 1983.

12. Okelo R. "Realistic Bond Strength of FRP Rebars in NSC from Beam Specimens". Journal of Aerospace Engineering, Volume 20 Issue 3 - July 2007.

13. Tighiouart B, Benmokrane B, Gao D. "Investigation of bond in concrete member with fibre reinforced polymer (FRP) bars". Construction and Building Materials. 1998;12(8):453-62. 


\section{LIST OF FIGURES AND TABLES:}

Fig. 1. Beams geometry

Rys. 1. Geometria belek

Fig. 2. Reinforcement of beams

Rys. 2. Zbrojenie belek

Fig. 3. Test setup

Rys. 3. Stanowisko badawcze

Fig. 4. Scheme of measurements

Rys. 4. Schemat oprzyrządowania

Fig. 5. Failure of the GFRP bar (GS-18-5.3) and steel bar (S-16-5.3) along the embedded length

Rys. 5. Zniszczenie pręta GFRP (GS-18-5.3) oraz pręta stalowego (S-16-5.3) na odcinku przyczepności

Fig.6. Loaded end slip-bond stress plot for GFRP bars

Rys. 6. Wykres przemieszczenie końca obciążonego - naprężenie dla prętów GFRP

Fig. 7. Free end slip-bond stress plot for GFRP bars

Rys. 7. Wykres przemieszczenie końca wolnego - naprężenie dla prętów GFRP

Fig. 8. Loaded end slip-bond stress plots for GFRP bars

Fig. 8. Wykres przemieszczenie końca obciążonego - naprężenie dla prętów stalowych

Fig. 9. Free end slip-bond stress plot for steel bar

Rys. 9. Wykres przemieszczenie końca wolnego - naprężenie dla prętów stalowych

Fig. 10. Loaded end slip-bond stress plots for GFRP and steel bars of $12 \mathrm{~mm}$ diameter

Rys. 10. Wykres przemieszczenie końca obciążonego - naprężenie dla prętów GFRP i prętów stalowych o średnicy $12 \mathrm{~mm}$

Fig. 11. Loaded end slip-bond stress plots for GFRP and steel bars of $16 \mathrm{~mm}$ diameter

Rys. 11. Wykres przemieszczenie końca obciążonego - naprężenie dla prętów GFRP i prętów stalowych o średnicy $16 \mathrm{~mm}$

Fig. 12. Loaded end slip-bond stress plots for GFRP and steel bars of $18 \mathrm{~mm}$ diameter

Rys. 12. Wykres przemieszczenie końca obciążonego - naprężenie dla prętów GFRP i prętów stalowych o średnicy $18 \mathrm{~mm}$

Tab. 1. Specimen details

Tab. 1. Szczegóły elementów badawczych

Tab. 2. Properties of GFRP and steel bars

Tab. 2. Właściwości prętów GFRP i stalowych

Tab. 3. Properties of concrete

Tab. 3. Właściwości betonu 
Tab. 4. Test results

Tab. 4. Wyniki badań 